\title{
An Analysis of Validity of Test Items in Chemistry Final Semester Examination for Vocational Students Majoring in Computer and Networking Engineering in Bantul Regency
}

\author{
Das Salirawati ${ }^{*}$, Anggiyani Ratnaningtyas Eka Nugraheni ${ }^{2}$, \\ Monday Ugiagbe Agbonkpolo ${ }^{3}$ \\ ${ }^{1}$ Department of Chemical Education, Yogyakarta State University, Indonesia \\ ${ }^{2}$ Karang Malang, Caturtunggal, Depok, Kabupaten Sleman, DIY, Indonesia \\ ${ }^{3}$ Benson Idahosa University, Benin City, Edo State, Nigeria \\ *Corresponding author: das_salirawati@uny.ac.id
}

Received: 19 August 2019; Accepted: 20 March 2020; Published: 5 April 2020

To cite this article (APA): Salirawati, D., Nugraheni, A. R. E., \& Agbonkpolo, M. U. (2020). An Analysis of validity of test items in chemistry final semester examination for vocational students majoring in computer and networking engineering in Bantul Regency. Asian Journal of Assessment in Teaching and Learning, 10(1), 32-40. https://doi.org/10.37134/ajatel.vol10.1.4.2020

To link to this article: https://doi.org/10.37134/ajatel.vol10.1.4.2020

\begin{abstract}
This research aims to investigate the quality of final examination test items given to the Computer and Networking Engineering students. The test items were developed by four chemistry teachers in the state vocational school (SVS) and private vocational school (PVS) in Bantul regency respectively. This research discusses on the quality of the test conducted and overall items developed by the chemistry teachers for both of SVS and PVS. The quality of the test items is measured by using four variables which are (1) material, construction, and language aspects, (2) cognitive level comparison, (3) the suitability of the materials tested to the materials covered in 2013 Curriculum, and (4) the suitability of the number of the test items given to the materials covered and time allocated. Ex-post facto research design was administered for this research. The sample of the research was taken from the final examination test items for the $10^{\text {th }}$ grade vocational school students of the Computer and Networking Engineering in Bantul regency for 2017/2018 academic year. The schools that involved in this research were represented by four schools for each of the SVS and PVS. The quality of the final examination test items was measured by using the instrument that was validated by three lecturers who are specialized in chemistry education. Each variable was analyzed descriptively using performance average. For variable 1, it was found that the quality of material, construction, and language of the final examination test items for both schools' categories were very good. For variable 2, the quality of cognitive level of the final examination test items by SVS was very poor but poor for the PVS. However, it was a reversal for variable 3 , when the PVS was very good prevailed by the mean percentage of the suitability of the materials tested to the materials covered in 2013 Curriculum compared to the SVS which was only in good category. For variable 4, the suitability of the number of test items given to the materials covered and time allocated, the mean percentage in SVS was very poor but poor for PVS. In conclusion, the overall of the quality test items developed by both the SVS and PVS chemistry teachers, was in good category for variables 1 and 3, and poor for variables 2 and 4. To conclude, this research able to observe that vocational school chemistry teachers for both SVS and PVS are able to construct good quality and appropriate test items.
\end{abstract}

Keywords: test items quality, final examination test items, vocational school, Chemistry teacher

\section{INTRODUCTION}

Anyone who does teaching work needs to know the consequences of his work. The teacher must know the extent to which students have absorbed and mastered the knowledge that has been taught. Conversely, students also need information about the results of their work. This only can be known if the teacher evaluates their teaching performances. Before conducting an evaluation, the teacher must conduct an assessment that is preceded by a specific measurement (Mokshein et al., 2015).

A measurement of learning outcomes is a way of gathering information which results can be 
accessed in the form of numbers called scores. On the other hand, an assessment of learning outcomes is a way of interpreting the scores obtained from the measurements by converting it through certain procedures and to refer it to make decisions. Actually the assessment of learning outcomes includes measuring learning outcomes, so the measuring instruments or tools are often referred to instruments and assessment tools (Meng \& Idris, 2015).

According to the Siswandani (2015) referring to Educational Assessment Standards, educational assessment can be defined as the process of gathering and processing information to measure the achievement of student learning outcomes. Assessment is a part of learning activities undertaken to determine the achievement of student competencies which include knowledge, skills, and attitudes (Sunarti \& Rahmawati, 2014).

According to Cizek (2000), evaluation is a process for determining the value or price by considering the results of observation or data collection obtained. A simple definition of evaluation is stated by Sudijono (1998), namely as an activity or process to measure and then assess the extent to which the goals have been implemented. The evaluation activities always begin with measurement activities namely the process of assigning numbers according to certain rules, continued with assessment, then ends with an evaluation.

In the evaluation, it consists of measurement and assessment activities, which both require instruments. Assessment instruments greatly affect the accuracy of the information obtained, in the form of data based on material understanding (cognitive aspects), attitudes (affective aspects) and skills (psychomotor aspects). Therefore, to make an assessment instrument good planning is needed, and at least it meets the theoretical validity (Wagiran et al., 2020). It is because the results of the assessment are crucial information, both for the teacher as feedback on the success or failure of teaching and for the student on the level of mastery that has been achieved. Hence, before conducting an assessment, the teacher needs to prepare assessment instruments properly and also know how to make good questions for the student. Actually, a good question instrument is one that has high validity and reliability. However, for teachers, the requirements seem heavy and a burden, except for assessment instruments that will be used on a broader scale, such as joint public tests.

Different types of questions are for assessment instruments that need to pay attention to the aspects of material, construction, and language. However, it seems that some teachers' have a lack understanding of these aspects, which can be proved by the results of a recent study that some students present the quality of odd semester test questions made by chemistry teachers from several high schools is relatively lacking. As a result, it is important for the teachers to know the important aspects that must be considered in the preparation of assessment instruments (Hamdan et al., 2019).

The first thing that is most crucial and must be accustomed to the teacher is to make a framework before running the item. The framework should consist of material and sub-material that need to be tested and distribute the questions by representing all of the existing sub-material. If the framework is not done, then the teacher does not know whether the items made include both in terms of the representation of all sub-material, the level of cognitive aspects from $\mathrm{C} 1$ to $\mathrm{C} 6$, and the level of difficulty. With the framework, it helps the teacher to prepare a well-planned evaluation.

Subsequently, the step is to choose the form of questions, between the objective questions or descriptions, depending on the purpose of the assessment that is carried out. For objective questions normally it takes a long time, thus only measure for the low-level of cognitive aspects, and students can guess the answers, but the advantages are easy and quick to correct, includes a lot of material, and high objective. Meanwhile the matter of description functional on vice versa. The objective questions are widely used in assessments in the form of multiple-choice questions. Some important things that need to be considered if the teacher makes objective questions in the form of multiple-choice quality, both in terms of material aspects, construction, and language. (Mardapi, 2012).

Then, end of semester assessment is an activity carried out by the teacher to measure the achievement of student competencies at the end of the semester. The scope of the assessment covers all indicators presented all BC in the semester. The end of semester assessment is scheduled for all schools simultaneously, but the questions used vary. It consists of questions made by MGMP and questions made by the subject teachers in each school. This is the part where the teacher is tested for their ability in making questions.

One of the requirements for a problem to be classified as good that it must be valid means that the problem that you want to be measured. There are two types of validity, firstly empirical validity which is known by conducting tests on a number of examinees working on the problem, and secondly 
the theoretical validity which consists of content validity and constructs that can be known from the framework made before making the questions that represent of all material tested and distributed proportionally from the cognitive level from $\mathrm{C} 1$ to $\mathrm{C} 6$.

A question that is used in the school level and any goal must meet the quality of good questions, at least minimum passed in the theoretical validity. But in reality, so far the teacher rarely or never even tested the validity of the questions empirically before the questions were given to the students. This is happened due to many factors such as the limitation of time, no opportunity to validate in the school, and no requirement demanded from the Local Education Office. On the other way, the habit of compiling questions that at least meets the theoretical validity must be applied, so the assessment results obtained are reflected on the expected cognitive competence.

Nowadays, the teachers' ability to compile learning outcomes questions has never been tested and known with certainty, both from the relevant department and the school itself. Besides, the reality shows that the questions compiled by the teacher are not tested for validity before they are used, even though the results of an accurate assessment require questions that meet the criteria of good questions (Nasir et al., 2017). The existence of questions such as daily tests, end of semester assessments, and grade-up assessments should be tested to meet the validity of the questions, even only used the theoretical validity, but the reality is not all the questions used for assessment meet all of these demands.

Based on this fact, this study wants to study empirically on how the quality of the final semester assessment questions in the Department of Computer and Network Engineering, both made by chemistry teachers of state vocational schools and private vocational schools in Bantul regency, and overall quality in terms of four variables, that are material aspects, construction, and language, cognitive level comparisons, the suitability of the material tested with the 2013 Curriculum, and the suitability of the number of questions with the breadth of concepts and the time allocation available (Hui \& Wei, 2013).

\section{RESEARCH METHODOLOGY}

This study aims to determine the quality of the final semester assessment questions in the Department of Computer and Network Engineering made by four chemistry teachers in SMK N and four private chemistry teachers in Bantul regency in terms of (1) aspects of material, construction, and language, (2) level comparisons cognitive, (3) the suitability of the material tested with the 2013 Curriculum, and (4) the suitability of the number of questions with the breadth of concepts and the time allocation available.

The sample of this research is in the form of chemistry assessment at the end of semester X of the Department of Computer and Network Engineering Vocational School which was compiled by eight vocational chemistry teachers in Bantul regency of the 2017/2018 academic year applying the 2013 curriculum, which divided to eight vocational schools, consist of four state vocational schools and four private vocational schools. The four state vocational schools include SMK N 1 Bantul, SMK N 1 Pleret, SMK N 1 Sedayu, and SMK N 1 Pundong, while four private vocational schools include Cokroaminoto Pandak Vocational School, Ki Ageng Archery-Jetis Vocational School, SMK Muhammadiyah 1 Imogiri, and Vocational School Ar-Rahmah Srambat. The samples were taken by purposive sampling, with consideration that the vocational schools has a Computer and Network Engineering Department in which there is chemistry subject. The research instrument of this study is in the form of an assessment sheet of the four variables are studied. The quality of assessment instrument was validated by three lecturers of Chemistry Department as reviewers then were revised according to the input or suggestions of the three reviewers.

The data obtained from the instrument quality assessment instrument is review based on the material, construction, and language aspects then analyzed by calculating the suitability of each item in a set of questions from each vocational schools and also all aspects, then converted into a percentage qualitatively based on the guidelines proposed by Supardi (2015). Lastly, the average quality of the questions from the variable for four questions of state vocational school and four questions of private vocational school, as well as the whole vocational school sample. This analysis applies to the other three variables. 


\section{RESULTS AND DISCUSSIONS}

The results are based on one by one analysis of question from each Vocational Schools in terms of material, construction, and language aspects obtained as shown in Table 1 and Table 2.

Table 1. The summary of the quality of grade of semester X evaluation assessment questions for state vocational schools in Bantul regency in terms of material, construction, and language aspects.

\begin{tabular}{|c|c|c|c|c|c|}
\hline \multirow[b]{2}{*}{ No. } & \multirow[b]{2}{*}{ Name of school } & \multirow[b]{2}{*}{$\begin{array}{l}\text { Number of } \\
\text { Questions }\end{array}$} & \multicolumn{3}{|c|}{ \% Average Conformity with Aspects } \\
\hline & & & $\begin{array}{c}\text { Material } \\
\text { (6 Indicators) }\end{array}$ & $\begin{array}{l}\text { Construction } \\
\text { (9 Indicators) }\end{array}$ & $\begin{array}{c}\text { Language } \\
\text { (9 Indicators) }\end{array}$ \\
\hline 1. & SMK N 1 Bantul & 40 & 87.5 & 96.4 & 93.7 \\
\hline 2. & SMK N 1 Pleret & 45 & 97.5 & 94.4 & 90.2 \\
\hline 3. & SMK N 1 Pundong & 40 & 99.6 & 86.9 & 90.7 \\
\hline 4. & SMK N 1 Sedayu & 25 & 75.0 & 97.8 & 92.7 \\
\hline
\end{tabular}

Tabel 2. The summary of the quality of grade semester X evaluation assessment questions for private vocational school in Bantul regency in terms of material, construction, and language aspects.

\begin{tabular}{|c|c|c|c|c|c|}
\hline \multirow[b]{2}{*}{ No. } & \multirow[b]{2}{*}{ Name of school } & \multirow[b]{2}{*}{$\begin{array}{l}\text { Number of } \\
\text { Questions }\end{array}$} & \multicolumn{3}{|c|}{ \% Average Conformity with Aspects } \\
\hline & & & $\begin{array}{c}\text { Material } \\
\text { (6 Indicators) }\end{array}$ & $\begin{array}{l}\text { Construction } \\
\text { (9 Indicators) }\end{array}$ & $\begin{array}{l}\text { Language } \\
\text { (9 Indicators) }\end{array}$ \\
\hline 1. & SMK Muh. 1 Imogiri & 35 & 100 & 90.9 & 92.2 \\
\hline 2. & SMK Ar-Rahmah Srandakan & 40 & 99.5 & 90.8 & 91.4 \\
\hline 3. & SMK Ki Ageng Pemanahan & 29 & 96.7 & 91.1 & 93.7 \\
\hline 4. & SMK Cokroaminoto Pandak & 50 & 89.6 & 98.5 & 91.1 \\
\hline & Average\% per Aspect & 154 & 96.5 & 92.8 & 92.1 \\
\hline & Category & & Very Good & Very Good & Very Good \\
\hline
\end{tabular}

The overall results of the question analysis for state and private vocational schools in terms of material, construction, and language aspects illustrated in Table 3.

Table 3. The summary of the quality of grade semester $X$ class evaluation assessment questions in state and private vocational schools in Bantul regency in terms of material, construction, and language aspects.

\begin{tabular}{|c|c|c|c|c|c|}
\hline \multirow[b]{2}{*}{ No. } & \multirow{2}{*}{$\begin{array}{c}\text { Type of } \\
\text { vocational } \\
\text { school }\end{array}$} & \multirow{2}{*}{$\begin{array}{c}\text { Number of } \\
\text { Questions }\end{array}$} & \multicolumn{3}{|c|}{$\%$ Average Conformity with Aspects } \\
\hline & & & $\begin{array}{c}\text { Material } \\
\text { (6 Indicators) }\end{array}$ & $\begin{array}{l}\text { Construction } \\
\text { (9 Indicators) }\end{array}$ & $\begin{array}{c}\text { Language } \\
\text { (9 Indicators) }\end{array}$ \\
\hline 1. & State & 150 & 89.9 & 93.9 & 91.8 \\
\hline 2. & Private & 154 & 96.5 & 92.8 & 92.1 \\
\hline \multicolumn{3}{|c|}{ Average per aspect } & 93.2 & 93.4 & 91.9 \\
\hline \multicolumn{3}{|c|}{ Category } & Very good & Very good & Very good \\
\hline
\end{tabular}

Based on the analysis of the quality of the questions in terms of the material, construction, and language aspects, the final semester assessment questions made by four chemistry teachers in state vocational schools in Bantul Regency indicate that the questions are in the very good category, with a mean per aspect in a row of $89.9 \%, 93.9 \%$, and $91.8 \%$. On the other side, for the final semester assessment questions made by four private vocational school chemistry teachers resulted in same category which is very good category, with a mean per aspect in a row of $96.5 \%, 92.8 \%$, and $92.1 \%$. Overall, the quality of the final semester assessment questions made by eight vocational chemistry teachers (four state vocational chemistry teachers and four private vocational chemistry teachers) are in a very good category with total average per aspect in a row of $93.2 \%, 93.4 \%$, and $91.9 \%$.

In this study, analysis of the quality of the questions on the construction aspects related to questions that specifically consist options in the form of numbers, negative statements (for example, except and no), and questions that have an introductory sentence or picture or graphic. 
The results of the analysis of these specific questions for state and private vocational schools can be illustrated in Table 4 below.

The results of the analysis of these questions are categorized in good, poor, and very good, respectively. This means that there are still many teachers that make questions with negative statements and not follow the rules of writing for good questions, where most of the questions that consist of negative statements and not emphasize the words 'except', 'not', or 'no' by italics or underlined or bolded (only one is used).

Table 4. The summary of the quality of semester $X$ class evaluation assessment questions in state and private vocational schools in Bantul regency for special questions.

\begin{tabular}{|c|c|c|c|c|c|c|c|}
\hline \multirow{3}{*}{ No. } & \multirow{3}{*}{ Special Questions } & \multirow{3}{*}{$\begin{array}{c}\text { Type of } \\
\text { vocational } \\
\text { school }\end{array}$} & \multirow{3}{*}{$\begin{array}{c}\text { Number } \\
\text { of } \\
\text { questions }\end{array}$} & \multicolumn{4}{|c|}{ Number of question } \\
\hline & & & & \multicolumn{2}{|c|}{ Suitable } & \multicolumn{2}{|c|}{$\begin{array}{c}\text { Not } \\
\text { Suitable }\end{array}$} \\
\hline & & & & $\Sigma$ & $\%$ & $\Sigma$ & $\%$ \\
\hline \multirow[t]{2}{*}{1.} & \multirow[t]{2}{*}{ Option in the form of numbers } & State & 49 & 37 & 75.5 & 12 & 24.5 \\
\hline & & Private & 14 & 9 & 64.3 & 5 & 35.7 \\
\hline \multicolumn{2}{|r|}{ Total } & & 63 & 46 & & 17 & \\
\hline \multicolumn{2}{|r|}{$\%$ Average of Conformity } & & & & 69.9 & & 30.1 \\
\hline \multicolumn{2}{|r|}{ Category } & & & & Good & & \\
\hline \multirow[t]{2}{*}{2.} & \multirow[t]{2}{*}{ Contains negative statements } & State & 15 & 5 & 33.3 & 10 & 66.7 \\
\hline & & Private & 15 & 5 & 33.3 & 10 & 66.7 \\
\hline \multicolumn{2}{|r|}{ Total } & & 30 & 10 & & 20 & \\
\hline \multicolumn{2}{|r|}{$\%$ Average of Conformity } & & & & 33.3 & & 66.7 \\
\hline \multicolumn{2}{|r|}{ Category } & & & & Poor & & \\
\hline \multirow[t]{2}{*}{3.} & \multirow{2}{*}{$\begin{array}{l}\text { Have an introductory sentence / } \\
\text { picture / graphic }\end{array}$} & State & 40 & 36 & 90.0 & 4 & 10.0 \\
\hline & & Private & 4 & 3 & 75.0 & 1 & 25.0 \\
\hline & Total & & 44 & 39 & & 5 & \\
\hline & $\%$ Average of Conformity & & & & 82.5 & & 17.5 \\
\hline & Category & & & & $\begin{array}{l}\text { Very } \\
\text { good }\end{array}$ & & \\
\hline
\end{tabular}

The results of a comparative analysis of cognitive levels are based on the revised Bloom's Taxonomy (Krathwol and Anderson, 2009). The comparison of cognitive levels of final grade assessment questions in the Department of Computer and Network Engineering of state vocational and private vocational schools in Bantul regency in the academic year of 2017/2018 can be presented in Table 5 and 6.

Tabel 5. The summary of Cognitive Level Comparison on class $X$ final semester assessment questions in state vocational schools in Bantul regency.

\begin{tabular}{|c|c|c|c|c|c|c|}
\hline \multirow{2}{*}{ No } & \multirow{2}{*}{ Name of school } & Number of & \multicolumn{4}{|c|}{ Cognitive level } \\
\cline { 4 - 7 } & & questions & C1 & C2 & C3 & C4,5,6 \\
\hline 1. & SMK N 1 Bantul & 40 & 9 & 4 & 13 & 14 \\
\hline 2. & SMK N 1 Pleret & 45 & 12 & 8 & 9 & 16 \\
\hline 3. & SMK N 1 Pundong & 40 & 14 & 6 & 8 & 12 \\
\hline 4. & SMK N 1 Sedayu & 25 & 4 & 2 & 10 & 9 \\
\hline & Total & 150 & 39 & 20 & 40 & 51 \\
\hline & (\%) Average & 100 & 26.0 & 13.3 & 26.7 & 34.0 \\
\hline
\end{tabular}

Tabel 6. Recapitulation of Cognitive Level Comparison on class X Final Semester Assessment Questions in Private Vocational Schools in Bantul Regency.

\begin{tabular}{|c|c|c|c|c|c|c|}
\hline \multirow{2}{*}{ No. } & \multirow{2}{*}{ Name of school } & Number & \multicolumn{4}{|c|}{ Cognitive level } \\
\cline { 4 - 7 } & & of & C1 & C2 & C3 & C4,5,6 \\
\hline
\end{tabular}


An Analysis of Validity of Test Items in Chemistry Final Semester Examination for Vocational Students Majoring in Computer and Networking Engineering in Bantul Regency

\begin{tabular}{|c|c|c|c|c|c|c|}
\hline & questions & & & & \\
\hline 1. & SMK Muh. 1 Imogiri & 35 & 17 & 16 & 1 & 1 \\
\hline 2. & SMK Ar-Rahmah Srandakan & 40 & 12 & 17 & 6 & 5 \\
\hline 3. & SMK Ki Ageng Pemanahan & 29 & 10 & 12 & 5 & 2 \\
\hline 4. & SMK Cokrominoto Pandak & 50 & 17 & 18 & 7 & 8 \\
\hline \multicolumn{2}{|c|}{ Total } & 154 & 56 & 63 & 19 & 16 \\
\hline (\%) Average & 100 & 36.4 & 40.9 & 12.3 & 10.4 \\
\hline
\end{tabular}

The overall results of the question analysis for public and private vocational schools in terms of cognitive level comparison can be presented in Table 7 below.

Tabel 7. The summary of cognitive level comparison on final year semester $\mathrm{X}$ grade assessment questions of state and private vocational schools in Bantul regency.

\begin{tabular}{|c|c|c|c|c|c|c|}
\hline \multirow[t]{2}{*}{ No. } & \multirow{2}{*}{$\begin{array}{c}\text { Type of } \\
\text { vocational } \\
\text { school }\end{array}$} & \multirow{2}{*}{$\begin{array}{c}\text { Number of } \\
\text { questions }\end{array}$} & \multicolumn{4}{|c|}{ \% Average of Cognitive Levels } \\
\hline & & & C1 & C2 & C3 & $\mathbf{C 4 , 5 , 6}$ \\
\hline 1. & State & 150 & 26.0 & 13.3 & 26.7 & 34.0 \\
\hline 2. & Private & 154 & 36.4 & 40.9 & 12.3 & 10.4 \\
\hline \multicolumn{3}{|c|}{ Total } & 62.4 & 54.2 & 39.0 & 44.4 \\
\hline \multicolumn{3}{|c|}{ Average } & 31.2 & 33.75 & 19.5 & 22.2 \\
\hline
\end{tabular}

Judging from the comparison for the state vocational schools for the percentage of cognitive level for C1: C2: C3: C4, 5, 6 shows a comparison of 26.0\%: 13.3\%: 26.7\%: 34\%. According to Sukardjo (2009), the ratio generally recommended for class $\mathrm{X}$ is $60 \%: 25 \%: 10 \%: 5 \%$. Based on the suitability criteria set out in this study are in the category of very poor, because there is no percentage of $\mathrm{C} 1$ : C2: C3: C4, 5, 6 that fits or approaches the percentage of the reference referred.

Unlikely with the case with private vocational schools, a comparison of $\mathrm{C} 1$ : $\mathrm{C} 2$ : $\mathrm{C} 3$ : $\mathrm{C} 4,5,6$ shows a ratio of $36.4 \%: 40.9 \%: 12.3 \%: 10.4 \%$. This comparison is approaching with the recommended ratio generally for class $\mathrm{X}$ (60\%: 25\%: 10\%: 5\%), where the questions including $\mathrm{C} 1$ and $\mathrm{C} 2$ are higher than $\mathrm{C} 3$ and $\mathrm{C} 4,5,6$. However, based on the suitability criteria set out in this study are at a disadvantage, because only one percentage is appropriate or close to the percentage of references referred to that is $\mathrm{C} 3$.

Overall the average of cognitive level for the final semester assessment questions of Class $\mathrm{X}$ state and private vocational schools in Bantul regency respectively for $\mathrm{C} 1$ : $\mathrm{C} 2$ : $\mathrm{C} 3$ : $\mathrm{C} 4,5,6$ shows a ratio of $31.2 \%: 33.75 \%: 19.5 \%: 22.2 \%$. This comparison is in the category of poor when compared from the suitability criteria set out in this study.

This mismatch of cognitive level does not mean the questions made by the teacher are not good, but specifically for this variable the percentage shift tends to be more dominated at high cognitive levels indicating the teachers' awareness to start making questions that can reveal the reasoning and logic of students starting from applying, analyzing, evaluating, and creating. In this era, indeed that there are demands for increasing the students' cognitive competence at a high level of cognitive dimensions (C4, $\mathrm{C} 5$, and C6) so that students are designed to deal with problems that the solutions require reasoning and logic. The questions as such are categorized as HOTS (Higher Order Thinking Skills).

Next, is the analysis is to examine the material tested in each question according to or not with 2013 SMK Chemistry Curriculum. The results for state vocational schools can be seen in Table 8 below.

Tabel 8. The summary of the suitability of the material tested (Final Semester Assessment Question) with 2013 Curriculum at state vocational schools in Bantul regency.

\begin{tabular}{|c|c|c|c|c|c|c|}
\hline \multirow{3}{*}{ No. } & \multirow{3}{*}{ Name of school } & \multirow{3}{*}{$\begin{array}{c}\text { Number of } \\
\text { questions }\end{array}$} & \multicolumn{4}{|c|}{ Number of questions } \\
\hline & & & \multicolumn{2}{|c|}{ Suitable } & \multicolumn{2}{|c|}{ Not Suitable } \\
\hline & & & $\Sigma$ & $\%$ & $\Sigma$ & $\%$ \\
\hline 1. & SMK N 1 Bantul & 40 & 25 & 62.5 & 15 & 37.5 \\
\hline 2. & SMK N 1 Pleret & 45 & 39 & 86.7 & 6 & 13.3 \\
\hline 3. & SMK N 1 Pundong & 40 & 40 & 100 & - & - \\
\hline 4. & SMK N 1 Sedayu & 25 & 6 & 24 & 19 & 76 \\
\hline & Total & 150 & 110 & & 40 & \\
\hline
\end{tabular}




\begin{tabular}{|c|c|c|c|c|c|}
\hline \% Average Conformity & & & 73.3 & & 26.7 \\
\hline Category & & & Good & & \\
\hline
\end{tabular}

Based on Table 8 shows that the end of semester assessment questions for state vocational schools in Bantul regency are included in good category with average percentage of $73.3 \%$. Sedayu Vocational School 1 tested more than half of the material that was not in accordance with the 2013 Chemistry Curriculum with percentage of $76 \%$. This is contrary to the results obtained from the problems of SMK N 1 Pundong which are entirely in accordance with the 2013 SMK Chemistry Curriculum by $100 \%$. This can be seen from the chemistry teachers' background which is able to correlate with the length of time teaching, which is 29 years (the longest of the three other chemistry teachers) and the experience of attending training for chemistry teacher at the province level. On the other hand, teachers from SMK N 1 Sedayu had only teaching experience for 13 years, shorter than the length time of teaching of the three other teachers.

The results of the analysis of the suitability of the material tested in each question with the 2013 Curriculum for private vocational schools can be seen in Table 9 below.

Tabel 9. The summary of the suitability of the material tested (Final Semester Assessment Question) with 2013 Curriculum at private vocational schools in Bantul regency.

\begin{tabular}{|c|c|c|c|c|c|c|}
\hline \multirow{3}{*}{ No. } & \multirow{3}{*}{ Name of school } & \multirow{3}{*}{$\begin{array}{c}\text { Number } \\
\text { of } \\
\text { questions }\end{array}$} & \multicolumn{4}{|c|}{ Number of questions } \\
\hline & & & \multicolumn{2}{|c|}{ Suitable } & \multicolumn{2}{|c|}{ Not Suitable } \\
\hline & & & $\Sigma$ & $\%$ & $\Sigma$ & $\%$ \\
\hline 1. & SMK Muh. 1 Imogiri & 35 & 32 & 91.4 & 3 & 8.6 \\
\hline 2. & SMK Ar-Rahmah Srandakan & 40 & 38 & 95.0 & 2 & 5 \\
\hline 3. & SMK Ki Ageng Pemanahan & 29 & 29 & 100 & - & - \\
\hline 4. & SMK Cokroaminoto Pandak & 50 & 40 & 80 & 10 & 20 \\
\hline & Total & 154 & 139 & & 15 & \\
\hline & $\%$ Average Conformity & & & 91.6 & & 8.4 \\
\hline & Category & & & $\begin{array}{l}\text { Very } \\
\text { good }\end{array}$ & & \\
\hline
\end{tabular}

Based on Table 9 shows the results of the analysis of the suitability of the final semester assessment questions with 2013 SMK Chemistry Curriculum from private vocational schools is greater with percentage $91.6 \%$ that is in very good category compared to the results of SMK N with $73.3 \%$ that is in good categories. Even though the teachers teach at the private vocational schools, all of the chemistry teachers obey the advice given by the local Education Office, by making questions referring to the 2013 curriculum described in the syllabus. This is proven by the four private vocational schools being sampled in this study. The level of suitability of the questions made with the 2013 Curriculum is $80 \%$ and above. Thus, for Ki Ageng Archery Vocational School, Jetis reached to 100\% compatibility.

The overall results of the question analysis for state and private vocational schools in terms of the suitability of the end of semester assessment questions with the 2013 SMK Chemistry Curriculum are presented in Table 10.

Tabel 10. The summary of the suitability of the material tested (Final Semester Assessment Question) with the 2013 Curriculum at state and private vocational schools in Bantul regency.

\begin{tabular}{|c|c|c|c|c|c|c|}
\hline \multirow{3}{*}{ No. } & \multirow{3}{*}{$\begin{array}{c}\text { Type of } \\
\text { vocational } \\
\text { school }\end{array}$} & \multirow{3}{*}{$\begin{array}{l}\text { Number of } \\
\text { questions }\end{array}$} & \multicolumn{4}{|c|}{ Number of questions } \\
\hline & & & \multicolumn{2}{|c|}{ Suitable } & \multicolumn{2}{|c|}{ Not Suitable } \\
\hline & & & $\Sigma$ & $\%$ & $\Sigma$ & $\%$ \\
\hline 1. & State & 150 & 110 & 73.3 & 40 & 26.7 \\
\hline 2. & Private & 154 & 139 & 91.6 & 15 & 8.4 \\
\hline \multicolumn{3}{|c|}{ Total } & 249 & 164.9 & 55 & 35.1 \\
\hline \multicolumn{3}{|c|}{$\%$ Average Conformity } & & 82.45 & & 17.55 \\
\hline \multicolumn{3}{|c|}{ Category } & & $\begin{array}{l}\text { Very } \\
\text { good }\end{array}$ & & \\
\hline
\end{tabular}

Overall the results of the analysis of the questions for state and private vocational schools in terms of the suitability of the final semester X grade assessment questions with the 2013 Curriculum are in very good 
category with $82.45 \%$. This shows that the teacher still refers to the applicable curriculum in making questions, even though there are some material from the questions that are not in accordance with the 2013 Curriculum. The material from the end of semester assessment questions that are not appropriate for the state vocational school covers the Chemical Basic Law and Chemical Calculation, Composite Nomenclature, and Redox, while for the private vocational school includes Stoichiometry, Acid Bases, and Composite Nomenclature.

The final analysis is to examine the suitability of the number of questions with the breadth of the concept and the time allocation available. The number of questions calculated is a matter that contains material in accordance with the 2013 Curriculum as mentioned in the Syllabus for Class X Odd Semesters. There are three basic chemistry subjects in vocational high school class X, namely Chemistry in Life, Atomic Structure and Periodic Systems, and Chemical Bonds. Each of them has $2 \times 2$ lesson hours, $4 \times 2$ lesson hours, and $6 \times 2$ lesson hours respectively.

This analysis is carried out using the established criteria in the guideline. In general, the criteria "according to" determined based on the breadth of the material covered, the allocation of time, and the number of questions given. In this case the breadth of the material also considered associated with the depth of matter. For example, if the number of sub-subject matter is large, but the allocation of time in the syllabus is small, it means that the subject matter is broad in concept but less depth, then the number of questions representing is small, and vice versa.

Based on the results of the final analysis, namely the suitability of the number of questions with the breadth of the concept and the time allocation available shows the percentage of the average suitability for the final semester assessment questions made by the chemistry teachers of the four state vocational schools are in the poor category, which is $33.3 \%$. Likewise, the questions made by the four chemistry teachers in private vocational schools are in the category of one gradation higher than state vocational schools, which is a fair category with $41.7 \%$. This is due to the fact that most of the eight teachers who made these questions (out of five teachers) did not arrange the framework first, so that the distribution of questions representing each of the main materials was not properly addressed. Overall the suitability of the number of questions with the breadth of material and the time allocation available in the Vocational Chemistry syllabus based on the 2013 Curriculum for state and private vocational schools in Bantul regency was $37.5 \%$, which is in the poor category.

Based on the overall results obtained in this study, it is suggested that vocational chemistry teachers, to learn more about how to arrange quality questions that meet various criteria of good questions, because the ability to make questions is part of the pedagogical competencies that must be possessed by a teacher.

The results of this study are expected to be followed up in the form of community service activities, especially the education community, namely vocational chemistry teachers that is provided in a workshop on the preparation of good chemistry questions, as well as direct practice, so that the results of this study are really beneficial in improving the quality of the questions made by the teacher which has been made with lack of attention.

\section{CONCLUSION}

Based on the results of this study, it can be concluded: (1) the quality of the final semester assessment questions in the Department of Computer and Network Engineering made by four chemistry teachers in state vocational schools and four private vocational chemistry teachers in Bantul regency in terms of aspects of material, construction, and language are in very good category. The cognitive level comparison for the four state vocational schools is very poor and for the four private vocational schools is also poor. The suitability of the material tested with the 2013 Vocational Chemistry Curriculum shows the average percentage for the four state vocational schools is $73.3 \%$ in good category, meanwhile for the four private vocational schools are $91.6 \%$ in very good category. The suitability of the number of questions with the breadth of concepts and the available time allocation, shows the average percentage for the four state vocational schools is $33.3 \%$ in very poor category, while for the four private vocational schools $41.7 \%$, in poor category. 
The quality of the final semester assessment questions in the Computer and Network Engineering Department made by all chemistry teachers of four state vocational schools and four private Chemistry teachers in Bantul regency in terms of aspects of material, construction, and language are in very good category. The comparison of cognitive levels is very poor. The suitability of the material tested with the 2013 Vocational Chemistry Curriculum shows that the total average is $82.45 \%$ that is in very good category, and the suitability of the number of questions with the breadth of concepts and time allocation available, showing a total average percentage of 37.5 that is in poor category. Based on the results of this study, several suggestions can be made, that are: (1) for the district or city or province Education Office of Yogyakarta, it is necessary to hold training or workshops for Chemistry teachers in particular and other subject teachers in general to compile the quality questions, to obtain direct knowledge and experience about the preparation of good questions; (2) for teachers, it is necessary to be followed up with an activity to improve making questions, so that the quality of final semester assessment questions and other exam questions arranged in the future is in better quality; (3) for other researchers, as a reference and source of data to be used in research with a wider coverage of population and wider area.

\section{REFERENCES}

Cizek, G. J. (2000). Pockets of Resistance in the Assessment Revolution. Educational Measurement: Issues and Practice, 19(2), 16.

Hamdan, N., Kiong, T. T., Heong, Y. M., Masran, S. H., Yunos, J. M., Mohamad, M. M., ... \& Haris, M. H. M. (2019). An Effectiveness of High Order Thinking Skills (HOTS) Self-Instructional Manual For Students'assignment Achievement. Journal of Technical Education and Training, 11(1)

Hui, H., \& Wei, W. (2013). A Study on Formative Assessment of EFL in the Multimedia-based Environment in China. Asian Journal of Assessment in Teaching and Learning, 3, 1-14.

Krathwohl, D. R., \& Anderson, L. W. (2009). A taxonomy for learning, teaching, and assessing: A revision of Bloom's taxonomy of educational objectives. Longman.

Siswandani, S. (2015). Penerapan Penilaian Berdasarkan Standar Penilaian Pendidikan (Permendikbud Nomor 66 Tahun 2013) Di Kelas Iv Sdn Junrejo 02 Kota Batu (Doctoral dissertation, University of Muhammadiyah Malang).

Mardapi, D. (2012). Pengukuran penilaian dan evaluasi pendidikan. Yogyakarta: Nuha Medika, 45.

Meng, C. C., \& Idris, N. (2015). Form Four Science Students' Perceptions of the Quality of Learning Experiences Provided by Assessments in STEM Related Subjects. Asian Journal of Assessment in Teaching and Learning, 5, 50-56.

Mokshein, S. E. M., Lebar, O., Rahmat, A., Dollah, M. U., Muhammad, A., Mansor, N. A., ... \& Noor, N. M. (2015). Development and Validation of Assessment Practice Inventory for Teacher Educators. Asian Journal of Assessment in Teaching and Learning, 5, 25-43.

Nasir, N., Adam, S. B., Rosli, N. N., Abdullah, M. S., \& Azman, M. N. A. (2017). Kompetensi Pembimbing dalam Sistem Latihan Kemahiran Dua Hala: Satu Sorotan Literatur. Sains Humanika, 9(1-5).

Sunarti, S. R. (2014). Penilaian Dalam Kurikulum 2013. Yogyakarta: CV Andi Offset.

Sudijono, A. (1998). Pengantar evaluasi pendidikan. PT RajaGrafindo.

Sukardjo. (2009). Penilaian Hasil Belajar Kimia. Yogyakarta: FMIPA - UNY.

Supardi (2015). Penilaian Autentik: Pembelajaran Afektif, Kognitif, dan Psikomotor (Konsep dan Aplikasi). Jakarta: RajaGrafindo Persada.

Wagiran, Retnowati, E., \& Azman, M. N. A. (2020). When Vocational Teachers Improve Their TPACK Competencies Through Lesson Study. International Journal of Psychosocial Rehabilitation, 24(4), 14757192. 